\title{
Enhanced ERbeta immunoexpression and apoptosis in the germ cells of cimetidine-treated rats Estela Sasso-Cerri
}

Address: Department of Morphology, Laboratory of Histology and Embryology, Dental School of São Paulo State University, Rua Humaitá, 1680,

Email: Estela Sasso-Cerri - esasso@foar.unesp.br

Published: 18 November 2009

Reproductive Biology and Endocrinology 2009, 7:127 doi:10.1 I86/1477-7827-7-127

This article is available from: http://www.rbej.com/content/7/1//27

(c) 2009 Sasso-Cerri; licensee BioMed Central Ltd.

This is an Open Access article distributed under the terms of the Creative Commons Attribution License (http://creativecommons.org/licenses/by/2.0), which permits unrestricted use, distribution, and reproduction in any medium, provided the original work is properly cited.
Received: 6 October 2009

Accepted: 18 November 2009

\begin{abstract}
Background: Cimetidine, refereed as antiandrogenic drug, causes hormonal changes in male patients such as increased testosterone and FSH levels. In the rat testis, structural alterations in the seminiferous tubules have been related to germ cell loss and Sertoli cell death by apoptosis. Regarding the important role of Sertoli cells in the conversion of testosterone into estrogen, via aromatase, the immunoexpression of estrogen receptors-beta (ERbeta) was evaluated in the germ cells of untreated and treated rats with cimetidine. A relationship between ERbeta immunoreactivity and apoptosis was also investigated in the germ cells of damaged tubules.
\end{abstract}

Methods: Immunohistochemistry for detection of ERbeta and TUNEL method were performed in testicular sections of adult male rats treated with $50 \mathrm{mg} / \mathrm{Kg}$ of cimetidine $(\mathrm{CmG})$ or saline solution (CG) for 52 days.

Results: In CG, a cytoplasmic immunoexpression for ERbeta was observed in spermatogonia, primary spermatocytes and spermatids. An evident ERbeta immunoreactivity was always observed in the flagellum and residual bodies of late spermatids. In CmG, the cytoplasm or cytoplasm and nuclei of germ cells of the damaged tubules by cimetidine showed enhanced ERbeta immunostaining. TUNEL-labeling was usually observed in the same germ cell types exhibiting enhanced ERbeta immunoreactivity.

Conclusion: The presence of ERbeta immunolabeling in the flagellum and residual bodies of spermatids reinforces the role of estrogen in spermiogenesis. The overexpression of ERbeta in the germ cells of $\mathrm{CmG}$ could be related to a possible interference of cimetidine on tubular androgenization and/or on the intratubular aromatase due to Sertoli cell damage. The parallelism between ERbeta overexpression and apoptosis indicates a participation of ERbeta on germ cell death.

\section{Background}

Additionally to testosterone, studies have demonstrated that estrogens play also a role in the local regulation of spermatogenesis [1-6]. Testosterone is converted into estrogens via cytochrome P450 - an aromatase enzyme [7]. In the testis, this enzyme is present in Sertoli and Leydig cells $[1,8]$, and has also been detected in germ cells $[1,3,4,8]$, suggesting that estrogen is locally produced 
from testosterone in the seminiferous epithelium. It has been demonstrated that the effect of estrogen action on the reproductive system is mediated by two estrogen receptors, $\mathrm{ER} \alpha$ and $\mathrm{ER} \beta[4,6,9-11]$. In the testis, ER $\beta$ is significantly expressed in comparison to $\mathrm{ER} \alpha$, mainly in the germ cells [12]. This type of receptor has been detected in germ cells of humans [13-17], rodents [2,10,18-20], and other mammalian species $[11,21]$, indicating that estrogens play a physiological role in the spermatogenic process via ER $\beta$.

In young and adult rodents, ER $\beta$ has been detected immunohistochemically in gonocytes, spermatogonia $[2,18]$, pachytene spermatocytes and spermatids $[2,10,18,20]$. The presence of ER $\beta$ in spermatocytes, round $[2,10,18]$ and elongate spermatids [3] has indicated a role of estrogens on spermatid maturation. This role has been reinforced by the fact that deficiency of aromatase leads to reduction in the number of spermatids [22]. On the other hand, low doses of estrogen can potentially cause severe spermatogenic cellular dysfunction [23]. Estrogen induces up-regulation of Fas and FasL in adult rat testis, resulting in the germ cell apoptosis [24]. It has been demonstrated that either extrinsic (cell death receptors) or intrinsic (mitochondria) pathways are involved in the estrogeninduced germ cell apoptosis [23].

Cimetidine is an $\mathrm{H}_{2}$-receptor antagonist that inhibits acid secretion and is clinically used for the treatment of gastric and duodenal ulcers [25]. However, some adverse effects have been described in male patients: a) loss of libido and impotence; 2) increased levels of FSH and testosterone [26] and 3) gynaecomastia [27]. The effects of cimetidine in adult castrated male rats androgenized with testosterone revealed a significant decrease in ventral prostate and seminal vesicle weights [28]. Moreover, this drug competes for tritiated dihydrotestosterone-binding sites in mouse kidney preparations [29]. Thus, this drug has demonstrated to be an anti-androgenic agent, competing for androgen receptors [28-30].

In male rats, cimetidine has caused increased FSH levels [31], reduction in testicular weight $[32,33]$ and structural alterations in the seminiferous tubules [31,33-36], including loss of germ cells by apoptosis [35]. The tubular alterations have suggested a possible antiandrogenic effect of cimetidine on the tubular androgenization $[33,34]$. Besides these effects, cimetidine induces peritubular myoid cell death $[31,35]$ and structural alterations in the Sertoli cell-basement membrane interface leading to Sertoli cell apoptosis [36]. Considering the antiandrogenic effect of cimetidine and the important role of Sertoli cells in the conversion of testosterone into estrogen, via aromatase, the immunoexpression of estrogen receptors
(ER $\beta$ ) in the germ cells of untreated and treated rats with cimetidine was evaluated. A relationship between ER $\beta$ immunoreactivity and apoptosis was also investigated in the germ cells of damaged tubules.

\section{Methods}

\section{Animals and treatment}

Ten adult Holtzman male rats weighing 250-300 g were maintained at $25^{\circ} \mathrm{C}$, standard lighting conditions (12-h light/dark cycle), fed laboratory rat chow and given water ad libitum. The animals were grouped in control (CG) and cimetidine $(\mathrm{CmG})$ groups containing five animals each. The animals from CmG received daily intraperitoneal injections containing aqueous solution of $50 \mathrm{mg}$ of cimetidine (Tagamet ${ }^{\oplus}$, SmithKline Beecham, Brazil) per kg of body weight for 52 days, period of a complete spermatogenic cycle [37]. The animals from CG received saline solution by the same route. Principles of laboratory animal care and national laws on animal use were observed. The protocol of this study was authorized by Ethical Committee for Animal Research of the Dental School of São Paulo State University (UNESP-Araraquara).

\section{Light microscopy}

The animals were anaesthetised and sacrificed with chloral hydrate and the testes were fixed in $4 \%$ formaldehyde (freshly prepared from paraformaldehyde) buffered at $\mathrm{pH}$ 7.2 with $0.1 \mathrm{M}$ sodium phosphate for 48 hours at room temperature. Subsequently, the specimens were dehydrated in graded ethanol and embedded in paraffin for detection of ER $\beta$ by immunohistochemistry and cell death by TUNEL method. Pieces of uterus from female rats were fixed in the same fixative and embedded in paraffin to be used as positive control for the immunohistochemistry.

\section{Immunohistochemistry for ER}

Testicular and uterine sections - used as positive control [38], were adhered to silanized slides, hydrated and maintained in citrate buffer $(0.001 \mathrm{M}$; pH 6.0), for $20 \mathrm{~min}$., in a microwave oven $\left(90^{\circ} \mathrm{C}\right)$ for activation of antigen. The sections were immersed in 3\% hydrogen peroxide (10 min.) for inactivation of endogenous peroxide. After washings in Tris- $\mathrm{HCl} 0.05 \mathrm{M}$; pH 7.5 buffer (TBS), the sections were incubated in primary antibodies (rabbit polyclonal IgG anti-rat estrogen receptor- $\beta$; Upstate Cell Signaling Solutions; Lake Placid, NY, USA), 1:200, diluted in TBS and $5 \% \mathrm{BSA}$, at $4{ }^{\circ} \mathrm{C}$. After $14 \mathrm{~h}$, the sections were washed in TBS and incubated in solution containing biotinylated anti-rabbit antibodies (LSAB-plus kit; DaKO Corporation, USA) for $30 \mathrm{~min}$. at room temperature, washed in TBS and incubated with streptavidin-peroxidase complex (LSAB-plus kit; DAKO) for $15 \mathrm{~min}$ at room temperature. After washings in TBS, the reaction was 
revealed with 0,06\% 3.3'-diaminobenzidine tetrahydrochloride (DAB - Sigma-Aldrich Chemical Co., St. Louis, USA). The sections were counterstained with haematoxylin, dehydrated and mounted in resin. To be sure that the immunoreaction could not be resulted from unspecific staining, testicular sections from CG and $\mathrm{CmG}$, used as negative controls, were performed following the same protocol, except that the incubation in the primary antibody was replaced by incubation in non-immune serum. The morphological analysis and capture of images were made by using light microscopes (Olympus, BX-50 and BX-51).

\section{Evaluation of the immunoreactivity}

Four testicular sections per animal from CG and CmG were used. In each section, the ER $\beta$-positive germ cells in six seminiferous tubules per section were analyzed according to the intensity of ER $\beta$ immunolabeling and scored as weak $(+)$, moderate $(++)$ or strong $(+++)[10]$.

\section{TUNEL method}

The TUNEL (Terminal deoxynucleotidyl-transferasemediated dUTP Nick End Labeling) method was performed as previously described $[35,36]$. The sections adhered to silanized slides (3-aminopropyltrithoxysylane - Sigma-Aldrich Chemical Co., St. Louis, USA) were treated with $20 \mu \mathrm{g} / \mathrm{ml}$ proteinase K (Sigma-Aldrich Chemical Co., St. Louis, USA) and immersed in 3\% hydrogen peroxide. After immersion in equilibration buffer, the sections were incubated in TdT enzyme at $37^{\circ} \mathrm{C}$ and, after 1 hour, the reaction was stopped with stop/wash buffer. The sections were incubated in anti-digoxigenin-peroxidase for $30 \mathrm{~min}$ and the reaction was revealed with $0.06 \%$ 3.3'diaminobenzidine tetrahydrochloride (DAB - SigmaAldrich Chemical Co., St. Louis, USA) and counterstained with Carazi's haematoxylin. Sections of involuting mammary gland, provided by the manufacturer of the Kit, were used as positive controls for the TUNEL method. Negative controls were incubated in a TdT enzyme-free solution.

\section{Results}

\section{Immunohistochemistry for ER}

The uterine sections, used as positive control, revealed an evident immunoreactivity in the epithelium, endometrial glands and muscle tissue (Fig. 1A). In the testicular sections, used as negative control, none immunoreactivity was observed (Fig. 1B).

In CG, an evident cytoplasmic immunostaining for estrogen receptors (ER $\beta$ ) was observed in the germ cells of the basal compartment (spermatogonia and leptotene spermatocytes) and in zygotene to diplotene spermatocytes in almost all stages (II-XIII). Round spermatids (stages IIVIII) showed a weak cytoplasmic immunostaining (Figs $1 \mathrm{C}-\mathrm{G})$. However, a conspicuous staining was noted in the
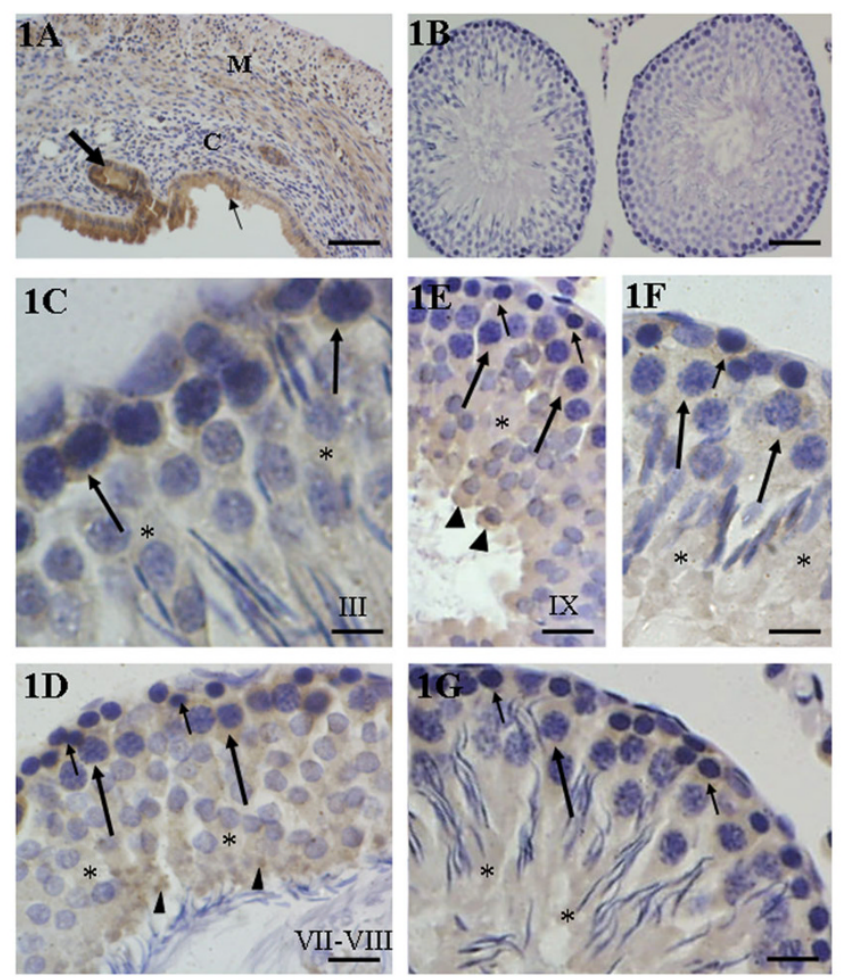

Figure I

IA-I G: Immunohistochemistry for detection of ER $\beta$ in the uterus (positive control) and in the testes of rats from CG. In IA, strong immunolabeling is observed in the epithelium (thin arrow) and endometrial gland (thick arrow). The connective (C) and muscle (M) tissues show a weak and moderate immunopositivity, respectively. In IB, none immunolabeling is observed in the testicular section used as negative control. In IC-IG, immunostaining is uniformly observed in the cytoplasm of germ cells of the basal compartment (short arrows), primary spermatocytes (long arrows), round and elongate spermatids (asterisks). An accentuated staining (arrowheads) is observed in the residual bodies (ID) and in the caudal portion of early elongating spermatids (IE). Scale bars: $100 \mu \mathrm{m}$ (IA); $60 \mu \mathrm{m}$ (IB); $10 \mu \mathrm{m}$ (IC); $2 \mathrm{I} \mu \mathrm{m}$ (ID and IE); I5 $\mu \mathrm{m}$ (IF and IG).

residual bodies derived from elongate spermatids in the tubules at stages VII and VIII and in the caudal portion of elongating spermatids in tubules at stage IX (Figs. 1D and $1 \mathrm{E})$.

The seminiferous epithelium of rats from CmG exhibiting lack of elongate spermatids, intraepithelial vacuoles and detached germ cells in the tubular lumen showed a similar immunostaining pattern to those of the control group. However, the nuclei of some round spermatids were also immunolabeled and a strong immunostaining was observed in the detached germ cells filling the tubular lumen (Fig. 2A). In the seminiferous tubules with severe 

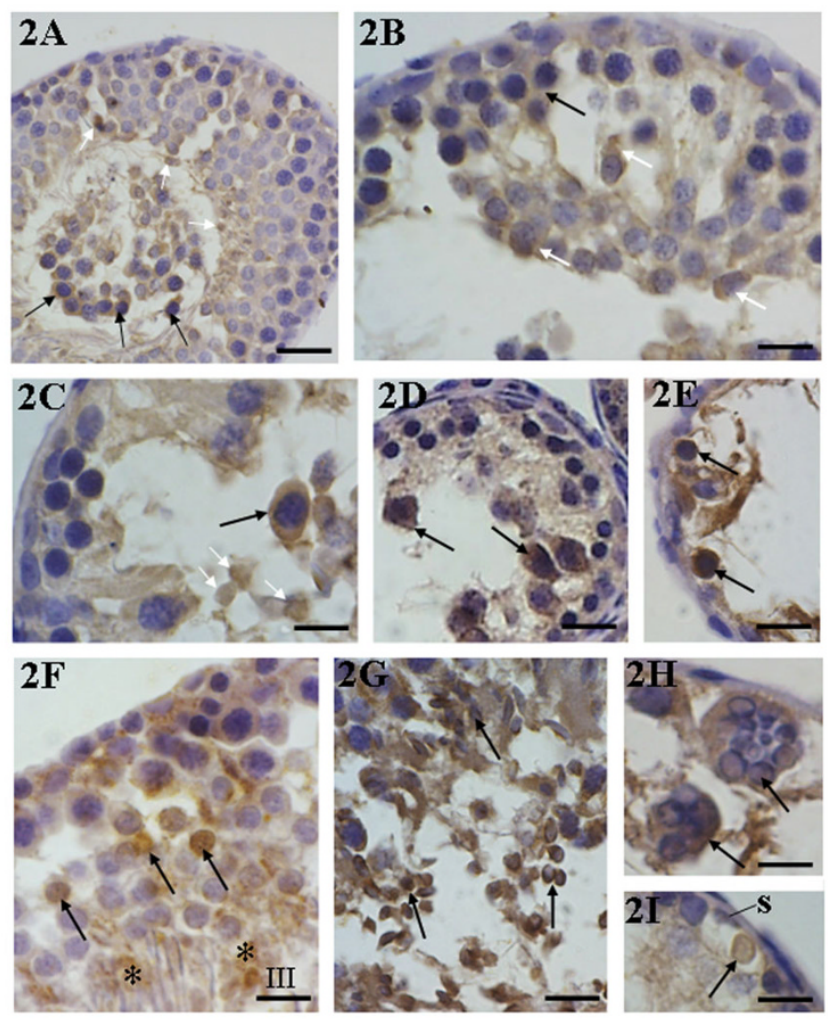

Figure 2

2A-2I: Immunohistochemistry for detection of ER $\beta$ in the testicular sections of rats from CmG. In 2A, the seminiferous tubule showing slight alterations exhibits a similar pattern of immunostaining of CG; however, some spermatid nuclei (white arrows) and the detached germ cells filling the lumen (black arrows) are strongly stained. In the damaged tubules (2B-2E), a strong immunopositivity (black arrows) is observed in the cytoplasm of primary spermatocytes (2B-2D) and germ cells of the basal compartment (2E). Note that the immunolabeling is observed in both cytoplasm (2B) and nucleus (2C) of spermatids (white arrows). In $\mathbf{2 F}$ and $\mathbf{2 G}$, strong positive immunolabeling is observed in the nucleus of round (2F) and elongating (2G) spermatids (arrows) and in the residual bodies (asterisks). In $\mathbf{2 H}$, the immunopositive giant multinucleated cells contain spermatids with peripheral condensed chromatin (arrows). In 2I, a positive germ cell is inside a vacuole (arrow) next to Sertoli cell nucleus (S). Scale bars: $28 \mu \mathrm{m}$ (2A and 2D); $20 \mu \mathrm{m}$ (2B, 2C, 2E-2I).

cellular depletion (Table 1), a strong immunopositivity was found in both nuclei and cytoplasm of spermatids, in the cytoplasm of primary spermatocytes and in the germ cells of the basal compartment (Figs. 2B-G). In late spermatids (tubules at stages II-V), a strong positive immunolabeling was observed in the residual bodies (Fig. 2F). Multinucleated giant cells derived from altered round spermatids showed nuclei with peripheral condensed chromatin (typical of apoptosis) and were also strongly positive to the immunoreaction (Fig. $2 \mathrm{H}$ ). In the maxi-
Table I: Scores (weak+, moderate++ and strong+++) of the ER $\beta$ immunoreactivity in the germ cells of rats from CG and CmG

\begin{tabular}{lcc}
\hline Germ Cells & CG & CmG \\
\hline Spermatogonia & ++ & +++ \\
Spermatocytes & ++ & $++/+++$ \\
Round spermatids & $+/++$ & $++/+++$ \\
Elongate spermatids & ++ & +++ \\
Residual bodies & $++/+++$ & +++
\end{tabular}

mally damaged tubules, some germ cell nuclei in the basal portion of the epithelium were strongly stained; some of them were inside a vacuole, next to Sertoli cell nucleus (Fig. 2I).

\section{ER immunostaining and TUNEL-positive germ cells}

In the damaged seminiferous tubules of cimetidinetreated rats, the TUNEL labeling was observed in the same germ cell types strongly immunostained for ER $\beta$, i.e. primary spermatocytes, round and elongate spermatids and giant multinucleated cells. In the ER $\beta$-immunostained cells, the nuclei also showed degenerative aspects, such as condensed chromatin, typical of apoptosis (Figs. 3A-J).

\section{Discussion}

\section{$E R$ immunoreactivity in untreated rats}

In the present study, the cellular ER $\beta$ immunolabeling was observed in spermatogonia, primary spermatocytes and spermatids, similarly to previous findings $[2,10,18,20,39]$. However, the immunoreactivity was always observed in the cytoplasm of these germ cells. Although ER is considered a nuclear receptor, the actual cellular localization of the estrogen receptors has been controversial. Estrogen modulates mitochondrial function, such as ATP production, mitochondrial membrane potential, and calcium concentration [40]. According to Yang [41], ER $\beta$ has demonstrated to be a mitochondrial protein rather than a nuclear receptor. Moreover, a number of studies have demonstrated that ER $\beta$ is mainly localized extranuclearly [reviewed by [42]]. Additionally to the nucleus, ER $\beta$ immunolabeling has been demonstrated in the cytoplasm of different cell types [41-43], including cells of the reproductive system $[2,10,19,39]$. A diffused immunostaining for ER $\beta$ has been demonstrated in the cytoplasm of spermatocytes [2] and in the seminiferous epithelium of bank vole [10]. In the testis of rat ABP transgenic mice, an evident immunostaining has been observed in the cytoplasm of pachytene spermatocytes and metaphase germ cells as well as a less intense cytoplasmic labeling in the elongate spermatids [19]. Moreover, ER $\beta$ immunostaining was also detected in human sperm, mainly in the midpiece, at the site where the mitochondria are packaged [16]. Thus, in agreement with these findings, the results of the present study reinforce the cytoplasmic role of estrogen via ER $\beta$ in the germ cells. 


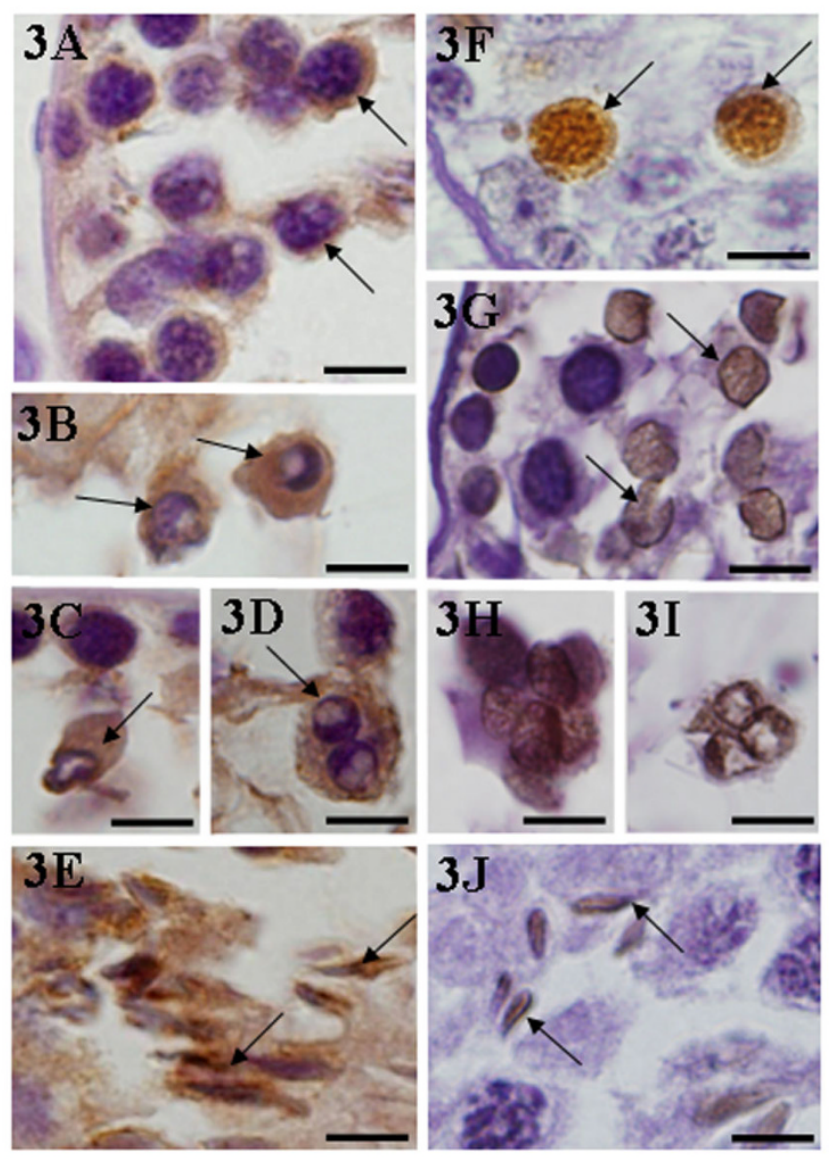

Figure 3

3A-3J: Immunohistochemistry for detection of ER- $\beta$ (Figs. 3A-3E) and TUNEL method (Figs. 3F-3J) in the seminiferous tubules affected by cimetidine (CmG). In $3 A-3 E$, spermatocytes (3A), round (3B and $3 C$ ), elongate (3E) spermatids and multinucleated cells derived from spermatids (3D) are positive for ER- $\beta$ immunohistochemistry (arrows). In these cells (3A-3D), the nuclei show degenerative aspect, typical of apoptosis. In 3F-3J, spermatocytes (3F), round (3G), elongate (3J) spermatids and giant multinucleated cells derived from spermatids $(\mathbf{3 H}$ and $\mathbf{3 I}$ ) are also TUNEL-positive (arrows). Scale bars: $8 \mu \mathrm{m}$.

Studies have demonstrated ER $\beta$ immunolabeling in round $[2,10,13,18]$ and elongate spermatids [14]. Moreover, knockout mice that lack a functional aromatase enzyme show a specific defect in the development of spermatids [22]. Therefore, these findings have confirmed that estrogen plays a role in the maturation of spermatids. In the present study, ER $\beta$ immunolabeling was observed in the cytoplasm of elongating spermatids, mainly at stage IX. Additionally, the residual bodies derivative from the final steps of spermiogenesis were also immunostained. It has been discussed that the differences concerning positivity and negativity in the cytoplasm of these cells are due to differences in the affinities of the antibodies by the amino acid sequences: $\mathrm{N}$ - or C-terminal region $[19,39]$. In these studies, a less intense but clear labeling was also demonstrated in the luminal compartment, corresponding to caudal portion (cytoplasm) of elongate spermatids and spermatozoa. The present results are compatible with the findings obtained by the authors probably due to the fact that the same amino acids (54-71 amino-terminal region) of rat estrogen receptor- $\beta$, such as used by the authors $[19,39]$, were used in the present study.

Additionally to the flagellum, the present findings revealed specific ER $\beta$ immunolabeling in the residual bodies of rat spermatids. These results are in agreement to previous studies, in which estrogen receptors immunoexpression have been demonstrated in excess residual cytoplasm [17] of human spermatozoa. In rodents, aromatase (a key enzyme that convert testosterone to estrogen) is observed to move from the Golgi apparatus to the cytoplasm during spermiogenesis and has been immunolocalized in both flagella and residual bodies [reviewed by [4]]. Therefore, the presence of ER $\beta$ in the same portions of spermatozoa in which aromatase has been detected reinforces the fact that spermiogenesis, including the formation of residual bodies, are estrogen-dependent processes.

\section{$E R$ immunoreactivity in cimetidine treated rats}

In the present study, an accentuated immunoreactivity for ER $\beta$ was observed in the damaged tubules by cimetidine. Spermatogonia, primary spermatocytes and spermatids in different steps of spermiogenesis exhibited strong cytoplasmic immunolabeling. In some germ cells, mainly spermatids, a conspicuous nuclear immunoexpression for ER $\beta$ was also observed. Cimetidine has demonstrated to cause severe alterations in the seminiferous tubules [31,33-36], including significant decrease in the diameter of tubules at androgen-dependent stages, detachment of spermatids from Sertoli cells [33] and germ cell loss by apoptosis [35]. Thus, a possible interference of cimetidine in the tubular androgenization has been suggested $[33,34]$. However, cimetidine has also demonstrated to exert a toxic direct effect on the peritubular tissue [31,35]. In a recent study, it has been demonstrated that Sertoli cell-basement membrane interface is structurally affected by cimetidine, leading to Sertoli cells death by apoptosis and significant reduction in the number of these cells [36]. It is known that Sertoli and germ cells are able to convert testosterone into estrogens via aromatase enzyme $[1,3,4,8]$. Thus, additionally to the antiandrogenic effect of cimetidine and the possible interference on tubular androgenization, the convertion of testosterone to estrogen by aromatase in the damaged tubules by cimetidine may be probably affected, due to Sertoli cell death. Studies have demonstrated a higher estrogen receptor immunoreactivity in different cerebral regions of animals whose source of estrogen was removed by aromatase inhibitors 
$[44,45]$ or in aromatase knockout (ArKO) mice [46], indicating that estrogen can down-regulates estrogen receptors. Regarding the seminiferous epithelium, a conspicuous ER $\beta$ immunolabeling was also detected in the germ cells of rat $\mathrm{ABP}$ transgenic mouse; in this rat model, aromatization to estrogen should also be impaired due to significant disruption in the intratubular androgen homeostasis [19]. Thus, it is conceivable to suggest that the increased ER $\beta$ immunoreactivity in the germ cells of affected tubules by cimetidine can be related to a possible interference of cimetidine on the tubular androgenization and/or to a possible intratubular aromatase or estrogen deficiency, due to Sertoli and germ cells damage. This is reinforced by the fact that cimetidine induces increase in the FSH levels in men [26] and in rats treated with the same dosage used in the present study [31]. It has been demonstrated that estrogen also plays a role in the feedback control of FSH concentrations [reviewed by $[4,47,48]]$. In men, the suppressive effect of testosterone on serum FSH is decreased by addition of aromatase inhibitor (testolactone), which in turn inhibits the conversion of testosterone into estrogen [47]. Thus, the increased FSH levels [31] associated to the impairment in the Sertoli cells caused by cimetidine $[35,36]$ support the idea that the ER-beta overexpression in the germ cells of damaged tubules by cimetidine can be related to a possible intratubular estrogen deficiency. However, further studies are necessary to confirm this possibility.

Studies have demonstrated a relationship between germ cell loss by apoptosis and deficiency of estrogen [8] or aromatase [22]. In a previous study, a massive germ cell loss by apoptosis has been demonstrated by TUNEL method in cimetidine-treated rats [35]. The results of the present study also revealed a parallelism between TUNEL-labeling and enhanced ER $\beta$ immunoreactivity in the same germ cell types. Thus, while spermatocytes cytoplasm and cytoplasm and nuclei of round and elongate spermatids showed enhanced ER $\beta$ immunoreactivity, these same cell types were also positive for the TUNEL method, as previously demonstrated [35] and observed in the present study. Moreover, germ cells strongly ER $\beta$-immunostained were within vacuoles next to Sertoli cells, suggesting phagocytosis, a common event observed during apoptosis [35]. In a recent study made in our laboratory, a similar parallelism between cytoplasmic ER $\beta$ overexpression and apoptosis has also been demonstrated in alveolar bone osteoclasts [49]. According to Nilsen et al. [50], ER $\beta$ acts as a mediator of apoptosis in cultured neurons. In patients with Alzheimer disease, an increased ER $\beta$ immunoreactivity was detected in the cytoplasm of degenerative neuronal cells of hippocampus [51]. Regarding the germ cells, a correlation between ER $\beta$ overexpression and apoptosis was also observed either in rat spermatocytes induced to apoptosis by short-term administration of methoxyacetic acid [20] or in rat ABP transgenic mouse [19]. In these studies, the authors suggest that these receptors play a role in the apoptotic process. Thus, the present findings corroborate to the idea that estrogen receptors (ER-beta) are related to the induction of apoptosis in the germ cells.

\section{Conclusion}

The results of the present study point to the cytoplasmic role of estrogen via ER $\beta$ in the germ cells. The presence of ER $\beta$ immunoreactivity in the flagellum and residual bodies of spermatids reinforces the role of estrogen on rat spermiogenesis.

Cimetidine interferes in the hormonal control of spermatogenesis leading to an accentuated ER $\beta$ immunolabeling in the germ cells. Future studies focusing on a possible intratubular aromatase deficiency would be useful to clarify the present findings. The parallelism between ER $\beta$ overexpression and apoptosis in the germ cells suggests a possible role of ER $\beta$ in the induction of germ cell death.

\section{Competing interests}

The author declares that they have no competing interests.

\section{Authors' contributions}

ESC carried out the treatments of animals, the histological processing, the immunohistochemistry and TUNEL methods and the respective analysis. ESC selected the images and participated, as only author, in the design, writing and final revision of the manuscript.

\section{Acknowledgements}

The author thanks Dr. Paulo Sérgio Cerri for advice in the preparation of the manuscript and Dr. José Vanderlei Menani for assistance during the capture of images. This work was supported by FUNDUNESP (00661/04-DFP) and FAPESP (06/54776-6).

\section{References}

I. Levallet J, Bilinska B, Mittre H, Genissel C, Fresnel J, Carreau S: Expression and immunolocalization of functional cytochrome $\mathbf{P 4 5 0}$ aromatase in mature rat testicular cells. Biol Reprod 1998, 58:919-926.

2. Saunders PTK, Fisher JS, Sharpe RM, Millar MR: Expression of oestrogen receptor beta $(E R \beta)$ occurs in multiple cell types, including some germ cells, in the rat testis. J Endocrinol 1998 , 156:13-17.

3. Carreau S, Bourguiba S, Lambarda S, Galeraud-Denis I, Genissel C, Bilinska B, Benahmed M, Levallet ]: Aromatase expression in male germ cells. J Steroid Biochem Mol Biol 200I, 79:203-208.

4. O'Donnell L, Robertson KM, Jones ME, Simpson ER: Estrogen and spermatogenesis. Endocr Rev 200I, 22:289-318.

5. Carreau S, Lambard S, Delalande C, Denis-Galeraud I, Bilinska B, Bourguiba S: Aromatase expression and role of estrogens in male gonad: a review. Reprod Biol Endocrinol 2003, I :35.

6. Carreau S, Delalande C, Silandre D, Bourguiba S, Lambard S: Aromatase and estrogen receptor in male reproduction. Mol Cell Endocrinol 2006, 246:65-68.

7. Simpson ER, Mahendroo MS, Means GD, Kilgore MW, Hinshelwood MM, Graham-Lorence S, Amarneh B, Ito Y, Fisher CR, Michael MD, Mendelson CR, Bulun SE: Aromatase cytochrome P450, the enzyme responsible for oestrogen biosynthesis. Endocr Rev 1994, 1 5:342-355. 
8. Carreau S, Genissel C, Bilińska B, Levallet J: The oestrogen sources in the testis and the reproductive tract of the male. Int J Androl 1999, 22:2 I I-223.

9. Pelletier G, Labrie C, Labrie F: Localization of oestrogen receptor $\alpha$, oestrogen receptor $\beta$ and androgen receptors in the rat reproductive organs. J Endocrinol 2000, I 65:359-370.

10. Bilińska B, Schmalz-Fraczzek B, Kotula M, Carreau S: Photoperioddependent capability of androgen aromatization and the role of estrogens in the bank vole testis visualized by means of immunohistochemistry. Mol Cell Endocrinol 200I, I 78: $189-198$.

I I. Rago V, Maggiolini M, Vivacqua A, Palma A, Carpino A: Differentia expression of estrogen receptors (ERalpha/ERbeta) in testis of mature and immature pigs. Anat Rec A Discov Mol Cell Evol Biol 2004, 28 I: |234-1239.

12. Gustafsson J-A: Estrogen receptor $\beta$ - a new dimension in estrogen mechanism of action. J Endocrinol 1999, 163:379-383.

13. Enmark E, Pelto-Huikko M, Grandien K, Lagercrantz S, Lagercrantz J, Fried G, Nordenskjöld M, Gustafsson JA: Human estrogen receptor $\beta$-gene structure, chromosomal localization, and expression pattern. I Clin Endocrinol Metab 1997, 82:4258-4265.

14. Pentikainen V, Erkkila K, Suomalainen L, Parvinen M, Dunkel L: Estradiol acts as a germ cell survival factor in the human testis in vitro. J Clin Endocrinol Metab 2000, 85:2057-2067.

15. Saunders PTK, Millar MR, Macpherson S, Irvine DS, Groome NP Evans LR, Sharpe RM, Scobie GA: ER $\beta$ I and the ER $\beta 2$ splice variant $(E R / c x / \beta 2)$ are expressed in distinct cell populations in the adult human testis. I Clin Endocrinol Metab 2002, 87:2706-27I5

16. Solakidi S, Psarra A-MG, Nikolaropoulos S, Sekeris CE: Estrogen receptors $\alpha$ and $\beta$ (ER $\alpha$ and $E R \beta)$ and androgen receptor (AR) in human sperm: localization of ER $\beta$ and $A R$ in mitochondria of the midpiece. Hum Reprod 2005, 20:348I-3487.

17. Rago V, Siciliano L, Aquila S, Carpino A: Detection of estrogen receptors ER-alpha and ER-beta in human ejaculated immature spermatozoa with excess residual cytoplasm. Reprod Biol Endocrinol 2006, 4:36.

18. van Pelt AMM, De Rooij DG, Burg B van der, Saag PT van der, Gustafsson J-A, Kuiper GGJM: Ontogeny of estrogen receptor- $\beta$ expression in rat testis. Endocrinology 1999, I 40:478-483.

19. Selva DM, Tirado OM, Toràn N, Suárez-Quian CA, Reventos J, Munell $\mathrm{F}$ : Estrogen receptor $\beta$ expression and apoptosis of spermatocytes of mice overexpressing a rat androgen-binding protein transgene. Biol Reprod 2004, 7 I: |46 I-I468.

20. Tirado OM, Selva DM, Toran N, Suarez-Quian CA, Jansen M, McDonnell DP, Reventos J, Munell F: Increased expression of estrogen receptor beta in pachytene spermatocytes after short-term methoxyacetic acid administration. J Androl 2004, 25:84-94.

21. Nie R, Zhou Q, Jassim E, Saunders PTK, Hess RA: Differential expression of estrogen receptors $\alpha$ and $\beta$ in the reproductive tracts of adult male dogs and cats. Biol Reprod 2002 66:1161-1168.

22. Robertson KM, O'Donnell L, Jones ME, Meachem SJ, Boon WC Fisher CR, Graves KH, Mclachlan RI, Simpson ER: Impairment of spermatogenesis in mice lacking a functional aromatase (cyp 19) gene. Proc Natl Acad Sci USA 1999, 96:7986-7991.

23. Mishra DP, Shaha C: Estrogen-induced spermatogenic cell apoptosis occurs via the mitochondrial pathway. Role of superoxide and nitric oxide. I Biol Chem 2005, 280:6|8|-6I96.

24. Nair R, Shaha C: Diethylstilbestrol induces rat spermatogenic cell apoptosis in vivo through increases expression of spermatogenic cell Fas/FasL system. I Biol Chem 2003, 278:6470-648I.

25. Ippoliti AF, Sturdevant RAL, Isenberg II, Binder M, Camacho R, Cano R, Cooney C, Kline MM, Koretz RL, Meyer JH, Samloff IM, Schwabe $A D$, Strom EA, Valenzuela JE, Wintroub RH: Cimetidine versus intensive antacid therapy for duodenal ulcer. Gastroenterology 1978, 74:393-395.

26. Wang C, Lai CL, Lam KC, Yeung KK: Effect of cimetidine on gonadal function in man. Br J Clin Pharmacol 1982, I 3:79|-794.

27. Peden NR, Boyd EJS, Browning MCK, Saunders JHB, Wormsley KG: Effects of two histamine $\mathbf{H}_{2}$-receptor blocking drugs on basal levels of gonadotrophins, prolactin, testosterone and oestradiol-I7 $\beta$ during treatment of duodenal ulcer in male patients. Acta Endocrinol |98I, 96:564-568.
28. Winters SJ, Banks JL, Loriaux DL: Cimetidine is an antiandrogen in the rat. Gastroenterology 1979, 76:504-508.

29. Funder JW, Mercer JE: Cimetidine, a histamine $\mathbf{H}_{\mathbf{2}}$ receptor antagonist, occupies androgen receptors. I Clin Endocrinol Metab 1979, 48:|89-|9|.

30. Takeshi S, Hai H, Sai S: Effects of the prenatal administration of cimetidine on testicular descent and genital differentiation in rats. Surgery 2002, I 3 I:301-305

31. França LR, Leal MC, Sasso-Cerri E, Vasconcelos A, Debeljuk L, Russell LD: Cimetidine (Tagamet) is a reproductive toxicant in male rats affecting peritubular cells. Biol Reprod 2000, 63:|403-|4I2.

32. Pereira OC: Some effects of cimetidine on the reproductive organs of rats. Gen Pharmacol 1987, I 8:197-199.

33. Sasso-Cerri E, Giovanoni M, Hayashi H, Miraglia SM: Morphological alterations and intratubular lipid inclusions as indicative of spermatogenic damage in cimetidine-treated rats. Arch Androl 200I, 46:5-13.

34. Gill M, Sareen ML, Sanyal SN: Effect of H2- receptor antagonists, cimetidine and ranitidine on reproductive functions in male mice. Indian J Exp Biol I99I, 29:900-906.

35. Sasso-Cerri E, Miraglia SM: In situ demonstration of both TUNEL-labeled germ cell and Sertoli cell in the cimetidinetreated rats. Histol Histopathol 2002, I 7:4 I I-4I7.

36. Sasso-Cerri E, Cerri PS: Morphological evidences indicate that the interference of cimetidine on the peritubular components is responsible for detachment and apoptosis of Sertoli cells. Reprod Biol Endocrinol 2008, 6:18.

37. Clermont $Y$, Leblond CP, Messier B: Duration of the cycle of the seminal epithelium of the rat. Arch Anat Microsc Morphol Exp 1959, 48(Suppl):37-55.

38. Wang H, Masironi B, Eriksson H, Sahlin L: A comparative study of estrogen receptors alpha and beta in the rat uterus. Biol Reprod 1999, 61:955-964.

39. Rosenfeld CS, Ganjam VK, Taylor JA, Yuan X, Stiehr JR, Hardy MP, Lubahn DB: Transcription and translation of estrogen receptor- $\beta$ in the male reproductive tract of estrogen receptor- $\alpha$ knock-out and wild-type mice. Endocrinology 1998 I 39:2982-2987.

40. Nilsen J, Brinton RD: Mechanism of estrogen-mediated neuroprotection: regulation of mitochondrial calcium and $\mathrm{Bc}-2$ expression. Proc Natl Acad Sci 2003, I 00:2842-2847.

4I. Yang SH, Liu R, Perez El, Men Y, Stevens SM, Valencia T, Brun-Zinkernagel AM, Prokai L, Will Y, Dykens J, Koulen P, Simpkins JW: Mitochondrial localization of estrogen receptor. Proc Natl Acad Sci 2004, I0I:4I30-4I35

42. Simpkins JW, Yang SH, Sarkar SN, Pearce V: Estrogen actions on mitochondria - Physiological and pathological implications. Mol Cell Endocrinol 2008, 290:51-59.

43. Gruber HE, Yamaguchi D, Ingram J, Leslie K, Huang W, Miller TA, Hanley EN Jr: Expression and localization of estrogen receptor $\beta$ in annulus cells of the human intervertebral disc and the mitogenic effect of 17 - $\beta$-estradiol in vitro. BMC Musculoskelet Disord 2002, 3:4.

44. Clancy AN, Zumpe D, Michael RP: Intracerebral infusion of an aromatase inhibitor, sexual behavior and brain estrogen receptor-like immunoreactivity in intact male rats. Neuroendocrinol 1995, 61:98-1II.

45. Bakker J, Pool CW, Sonnemans M, van Leeuwen FW, Slob AK: Quantitative estimation of estrogen and androgen receptorimmunoreactive cells in the forebrain of neonatally estrogen-deprived male rats. Neurosci 1997, 77:911-919.

46. Agarwal VR, Sinton CM, Liang C, Fisher C, German DC, Simpson ER Upregulation of estrogen receptors in the forebrain of aromatase knockout (ArKO) mice. Mol Cell Endocrinol 2000, 162:9-16.

47. Finkelstein JS, O'Dea LS, Whitcomb RW, Crowley WF: Sex steroid control of gonadotropin secretion in the human male. II. Effects of estradiol administration in normal and GnRH deficient men. J Clin Endocrinol Metab 1991, 74:62I-628.

48. Bagatell C], Dahl KD, Bremner W]: The direct pituitary effect of testosterone to inhibit gonadotropin secretion in men is partially mediated by aromatization to estradiol. J Androl 1994 , I5:|5-2|

49. Cruzoé-Souza M, Sasso-Cerri E, Cerri PS: Immunohistochemical detection of ER $\beta$ in alveolar bone cells of estradiol-treated 
female rats: possible direct action of estrogen on osteoclast life span. J Anat 2009, 21 5:673-68I.

50. Nilsen J, Mor G, Naftolin F: Estrogen-regulated developmental neuronal apoptosis is determined by estrogen receptor subtype and the Fas/Fas ligand system. J Neurobiol 2000, 43:64-78.

5I. Savaskan E, Olivieri G, Meier F, Ravid R, Muller-Spahn F: Hippocampal estrogen beta-receptor immunoreactivity is increased in Alzheimer's disease. Brain Res 200I, 908:1 I3-119.

Publish with Bio Med Central and every scientist can read your work free of charge

"BioMed Central will be the most significant development for disseminating the results of biomedical research in our lifetime. "

Sir Paul Nurse, Cancer Research UK

Your research papers will be:

- available free of charge to the entire biomedical community

- peer reviewed and published immediately upon acceptance

- cited in PubMed and archived on PubMed Central

- yours - you keep the copyright

Submit your manuscript here:

http://www.biomedcentral.com/info/publishing_adv.asp 